\title{
SERVICES AND CREATING VALUE FOR CUSTOMERS - MARKETING APPROACH
}

\section{MirosŁaWA PLUTA-OLEARNIK}

Wrocław Uniwersity of Economics, POLAND

e-mail: miroslawa.pluta-olearnik@ue.wroc.pl

\begin{tabular}{l|l}
$\begin{array}{l}\text { RECEIVED } \\
\text { JCCEPTED }\end{array}$ & $\begin{array}{l}\text { 12 July } 2017 \\
\text { 15 December } 2017\end{array}$ \\
CLASSIFICATION & M31, L80 \\
KEYWORDS & $\begin{array}{l}\text { marketing, services, value for customer, service logic } \\
\text { Perceiving enterprise marketing through the prism of value provided to customers is already a well-established } \\
\text { approach to management expertise, including the field of marketing. The article addresses the role of services } \\
\text { in the delivery of this value. The aim of the article is to review the state of research in this area based on } \\
\text { scientific analysis of Polish and foreign journals. The result of the study is the identification of various research } \\
\text { approaches to exploit the potential inherent in the service in order to create and provide value to the customer. } \\
\text { In further research on the business model and competitiveness of enterprises, it is possible to develop an } \\
\text { innovative concept of so-called service dominance logic in marketing. }\end{array}$
\end{tabular}

\section{Introduction}

Value for the customer can be considered in the context of the business model adopted by the company. In the light of research in the area of management, it can be stated that there is a wide range of business model concepts, and it is difficult to clearly indicate the elements that determine its success. The most frequently cited elements of business models are: the position of the enterprise in the value chain, customer value, sources of 
revenue, competitive strategy, resources, competencies, external relations, products and services offered, costs (Obłój, 2002; Gołębiewski, 2008; Jabłoński, 2013). The success of a specific business model is combined with the proposition of value for customers, which means that it creates value for the customer and ensures its delivery. The tool for the implementation of the business model is the strategy of the organisation and marketing strategy associated with it.

The article focuses on the potential of a marketing approach to customer value creation, which is most often perceived as a relation between the benefits provided by the product and all the costs associated with acquiring the benefits of the product (Hawkins et al., 2004; Horovitz, 2006). The purpose of this article is to present the role of services in the process of creating and providing value to the customer, starting with the narrow view in which the service is perceived as one of the elements of a more or less extensive offer for the customer, to the innovative concept, presented in the new concept of the logic of domination in service marketing (Vargo, Lusch, 2004).

The result of research into the role of service in the creation and delivery of value for customers is to identify new approaches that leverage service-based capabilities and to identify directions for desired changes in business models and in building a competitive advantage for contemporary businesses.

\section{Litepgture review}

Nowadays, marketing is defined as broadly understood management of the value creation process for the customer in order to achieve a certain competitive position in the market (Doyle, 2003; Kotler, Keller, 2012). Its main three streams include: creation and delivery of value for the customer (Doligalski, 2013), customer value management (Kumar, 2010) and customer perception of value (Gronroos, 2007).

One of the main streams of research in this area is customer value management, with the emphasis on its process character by indicating the following four stages of this process:

- defining value for the customer,

- value creation,

- value communication,

- providing value (Szymura-Tyc, 2004).

The first stage, i.e. defining value, leads to establishing the core value offered to the customer, i.e. determining the product/service characteristics that are the basis of the benefits provided to the customer relative to the price and other costs borne by the customer. The package of customer value should be well adapted to the resources and competencies of the company, it should distinguish the company from the competition and provide value for the company in the long run.

The next stage, creation of value for the customer, involves making decisions and coordinating actions that facilitate the physical processes of creating the basic and additional values for the customer. They are held both inside the organisation and outside in cooperation with partners and suppliers. At this stage, attention is drawn to the need to interact with the customers and encourage them to contribute to the final offer (value). In practice, it means customer relationship management, customer coaching, and sharing knowledge with the customer, so the end product/service meets the high level of customer expectations.

The third stage, communicating value to the customer, is supposed to build an organization's image and the product/service offer, as well as establish long-term customer relationships. Private, group and mass communication tools are used here, with an increasing share of new technologies and the Internet. 
The last step, providing value to the customer, means customer service in a specific form, location, time, and agreed terms of payment.

At each of the mentioned stages of the customer value management process there is room for services as essential components of the offer of benefits for the customer. However, the question remains, what role do they play? Referring to the so-called customer value map, we can see a number of instances where services are the source of this value.

The value map of the above-mentioned authors includes the following types of benefits for the customer (Dobiegala-Korona, Doligalski, 2010):

- tighter adaptation of the product to individual needs and expectations (value of function),

- choice of form; this value gives customers the choice of shape, size, styling, equipment, convenience of use (value of form),

- availability of the offer at a time convenient to the customer or whenever they need it (value of time),

- delivery of the products to a place that is convenient for purchase or where the consumer needs it (value of place),

- differentiation of the means of transferring the right to use the product from the seller or producer to the customer (value of possession); this can be a form of purchase for cash, leasing, credit sales supplemented by the company's taking over the formalities involved in acquiring a loan, etc.,

- adaptation of information about the offer, terms of use of the product, purchase conditions etc. to individual customer needs, and answering the customer's inquiries whenever they are voiced, e.g. 24/7 (value of communication),

- education of customers in order to help them maximise the use of product features (value of education),

- customer experience in the periods prior to purchase and during product life (value of experience).

When exploring the level of value provided to the customer, it is important to be aware that it is the result of a subjective evaluation of the benefits received and the costs by the customer.

\section{Method}

As a result of the critical analysis of the literature will be identified four approaches to the components that create value for the customer in the field of services. This analysis shows the evolution in the development of the theory of creating value for the customer in service sector, including the new approach (Service Dominant Logic). The article is based on publications that make a significant contribution to the development of knowledge about service management focused on the customer value creation and available in the EBSCO database.

\section{Results}

First approach - The value for the customer in specific services is created in the sphere of unique resources and competencies of the service provider and, subsequently, elements of service, which are difficult to copy, by the competition. This is typical for the resource-related approach in management. An example of such an approach is the study of specific service providers whose strategies are focused on customer satisfaction and customer loyalty. The results of these studies pertain to various service industries. For example, in the services of Polish tourist offices, customer value is associated with: quality of the offer, price, quality of customer service, professionalism of employees, reputation of the office (Chlipała, 2009), whereas in the case of low-cost Ryanair services, the value 
for the customer is a result of an extensive network of flight connections, competitively low ticket prices, passenger safety (Liczmańska et al., 2016).

Second approach - Value for the customer is perceived through a structural model that includes four levels of value: basic value (core product, basic benefit), additional value (e.g. complementary services), value extended by customer service, e.g. design, consulting, financial services and commercial services. It is also a resource-related approach with elements of a relational approach. It has the potential for additional value for the customer through the services added to the offered products. What enriches the existing approaches of the structural model is the recognition of customer service and relationships as distinctive elements of value creation for the customer. In practice, this is typical for the commercial sphere, where companies compete through their specialised customer service at every stage of the sales process and cooperate with specialised service providers. An example of such a strategy is the collaboration of Swedish Ikea with American Apple to provide customers with a unique mobile app which allows the "testing" of furniture in the space of the apartment. The technologically advanced application utilises Augmented Reality and is available on Apple's mobile devices.

Third approach - The value for the customer in the field of services considered in the context of the creation and development of system products. It is a process and relational approach. By describing the characteristics of system products, L. Żabiński's (2012) draws attention to such features as: satisfying complex needs (e.g. complex leisure needs), high innovation (including technological advancements), the need to cooperate with many entities in the process of product creation and sale, often globally, as well as positive brand value. A particular feature of system products is, therefore, to provide value to the customer by satisfying the complexity of their needs and expectations rather than the needs and expectations associated with them.

An example of the development of system products is the residential property market in Poland and the so-called developer multi-product, which is the offer of a "city within the city." The idea is to create multifunctional buildings with the future of residents in mind, which means the use of large spaces where people can live, work, shop and actively spend their leisure time. Implementing such an offer requires the developer's cooperation with a number of environmental entities to ensure the fulfilment of all the complex needs of the inhabitants of such a "city" - the system product (Pluta-Olearnik, 2015).

Fourth approach - The value for the customer is perceived in the light of the so-called Service Dominant Logic. It is a concept developed by S.L. Vargo and R.F. Lusch (2004). The core of this concept is the idea of cocreation, which is the opposite of Goods Dominant Logic. According to the above-mentioned authors, the value of any products (material goods and services) for the customer is created while they are consumed, and the producers' offers are only propositions of value. The Service Dominant Logic concerns not only typical service companies but also the providers of material goods.

This concept defines service as "the application of specialised competences, knowledge and skills in the process of undertaking activities, processes and activities for others" (Vargo, Lusch, 2004; Edvardsson et al., 2011). Due to the limitations of internal intangible resources, companies must reach for outside sources (customers and business partners) and marketing is responsible for configuring these resources. In subsequent years, service logic concept was the subject of numerous conceptual publications as well as a relatively small number of quality empirical studies.

The pioneers of research in Poland were J. Mazur and P. Zaborek (2014a), who published the methodology and results of quantitative empirical research in Polish and foreign journals, raising a visible interest and discussion 
among international researchers. The authors analysed whether the implementation of service logic had positive results for Polish companies, measured by the increase in customer loyalty. In these studies, the attributes of service logic were measured by twenty-three observable variables, including five hidden variables representing enterprise involvement in service logic: 1) orientation on intangible assets; 2) creating conditions for dialogue; 3) stimulating dialogue with customers and between them; 4) orientation on long-term relationships; 5) customer experience management (2014). The obtained results proved that service companies, in contrast to production companies, show greater commitment to service logic. However, in the "advanced" segment of enterprises called "True Service Logic," $62 \%$ of service enterprises and $38 \%$ of manufacturing companies were recorded. Significant statistical differences identified in the study concerned three of the six factors (hidden variables):

- more successful creation of conditions for dialogue - two-way communication with customers,

- more successful stimulation of dialogue with customers and between customers, especially through the use of modern media (e.g. the Internet),

- greater focus on management of customer experience rather than product offers (Mazur, Zaborek, 2014b).

The results of these studies have confirmed the hypothesis of the economic (financial) validity of the implementation of service logic in enterprises. The authors also point out that the growth of the Internet has strengthened the position of consumers in the market, and large companies have recognised the opportunities which arise from treating consumers as co-creators of value, as suggested by Prahalad and Ramaswamy (2004) in their works about the future of competition.

\section{Conclusions}

The article presents the evolution of approaches to understanding the role of services in the context of management of value for the customer. The next approaches developed with the increase in marketing knowledge, i.e. the use of intangible assets, the co-creation of value with the customer, and the building and maintenance of relationships as elements of establishing a competitive advantage for the company.

By learning the customer value creation process, the enterprise can more successfully identify customer expectations and, more importantly, it can identify problems the customer does not see. By resolving these problems, the supplier can offer the customer more value than the competitor. Creation and delivery of value to the customer in marketing processes is a prerequisite for building a competitive advantage, and in relation to services, it primarily requires the development of customer relationships (Siemieniako, 2017). In light of the latest service concept, market dominance in the marketplace provides customers only with value proposition in the form of products or services, while value for the customer is revealed in the process of utilising them. This represents a breakthrough in the meaning of the process of creating (contributing) and providing value to the customer in the market not only of services but also of material goods.

Finally, by adopting the point of view of the business model, it is worth to quote the opinion of B. DobiegałaKorona (2006) that a customer value management strategy to ensure high customer value is a critical part of the enterprise. Investments in the customer must be treated as long-term return strategies. Investments undertaken in the current period will bring benefits in the future. The more precisely the customer groups are identified on the basis of their expectations and generated value for them, the better tailored will be customer value strategies, and the strategies for the increased value of customers for the enterprise will be more effective. 


\section{Refierences}

Chlipała, P. (2009). Wartość dla klienta jako płaszczyzna budowania relacji przedsiębiorstwo usługowe - klient. Zeszyty Naukowe Uniwersytetu Szczecińskiego 558. Ekonomiczne Problemy Usług, 41, 27-37.

Dobiegała-Korona, B. (2006). Wartość klienta czy wartość dla klienta. Kwartalnik Nauk o Przedsiębiorstwie, 1.

Dobiegała-Korona, B., Doligalski T., (eds.) (2010). Zarządzanie wartością klienta. Pomiar i strategie. Warszawa: Poltext.

Doligalski, T. (2013). Internet w zarządzaniu wartością dla klienta. Warszawa: Oficyna Wydawnicza Szkoły Głównej Handlowej.

Doyle, P. (2003). Marketing wartości. Warszawa: Felberg SJA.

Edvardsson, R.N. et al. (2011). Does service dominant design result in a better service system? Journal of Service Management, 2 (22).

Gołębiewski, T., Dudzik, T., Lewandowska. M., Witek-Hejduk M. (2008). Modele biznesu polskich przedsiębiorstw. Warszawa: Szkoła Główna Handlowa.

Grönroos, Ch. (2007). In Search of New Logic for Marketing. Foundations of Contemporary Theory. London: John Wiley \& Sons, Ltd.

Grönroos, Ch. (2008). Service logic revisited: Who creates value? and who co-creates? European Business Review, 4 (20).

Hawkins, D.I., Best, R.J., Coney, K.A., Koch, E.C. (2004). Consumer Behavior Building Marketing Strategy. New York: McGrowHill.

Horowitz, J. (2006). Strategia obsługi klienta. Warszawa: PWE.

Jabłoński, A. (2013). Model biznesu. Myślenie strategiczne. Warszawa: Difin.

Kotler P., Marketing.Poznań: Rebis.

Kotler, P., Keller, K.L. (2012). Marketing. Poznań: Rebis.

Kumar V, (2010) Zarządzanie wartością klienta. Warszawa: Wydawnictwo Naukowe PWN.

Liczmańska, K., Kuczyńska, M. (2016). Wartość dla klienta jako główny element biznesu linii lotniczych Ryanair. Acta Universitatis Nicolai Copernici, 3, 202-205.

Mazur, J., Zaborek, P. (2014). Czy usługodawcy stosują logikę usługową w marketingu? Prace Naukowe Uniwersytetu Ekonomicznego we Wrocławiu, 353, 25.

Mazur, J., Zaborek, P. (2014a). Logika usługowa a lojalność klientów. In: A. Czubała, P. Hadrian, J.W. Wiktor (eds.). Marketing w 25-leciu gospodarki rynkowej w Polsce (pp. 544-552). Warszawa: PWE.

Obłój, K.( 2002). Tworzywo skutecznych strategii. Warszawa: PWE.

http:// bussinesinsider.com.pl technologie/nowe-technologie/ikea (5.04.2017).

Pluta-Olearnik, M. (2015). Real estate development multi-produkt. Journal of Economics and Management, University of Economics in Katowice, 4 (22), 142.

Prahalad, C.K., Ramaswamy, V. (2004). The future of competition: Creating unique value with customers. Boston: MA: Harvard.

Siemieniako, D. (2012). Logika usługowej dominacji w marketingu - podstawowe pojęcia i konsekwencje w zarządzaniu. Retrieved from: https://www.academia.edu (4.05.2017).

Szymura-Tyc, M. (2005), Marketing w procesie tworzenia wartości dla klienta i przedsiębiorstwa. Katowice: Akademia Ekonomiczna.

Szymura-Tyc, M. (2004). Marketing we współczesnych procesach tworzenia wartości dla klienta i przedsiębiorstwa. Acta Universitais Lodziensis, Folia Oeconomica, 179, 207-213.

Vargo, S.L., Lusch, R.F. (2004). Evolving to a New Dominant Logic for marketing. Journal of Marketing, 1 (68).

Żabiński, L. (ed.) (2012). Marketing produktów systemowych. Warszawa: PWE.

Cite this article aS: Pluta-Olearnik, M. (2018). Services and creating value for customers - marketing approach. European Journal of Service Management, 2 (26), 193-198. DOI: 10.18276/ejsm.2018.26-24. 